\title{
DO MEDO DO ENFRENTAMENTO AO ENFRENTAMENTO DO MEDO: REAÇÕES DIANTE DA POLÍCIA EM OUTROS TEMPOS, DE DOMINGOS PELLEGRINI
}

\author{
Raquel Belisario da Silva ${ }^{1}$
}

\begin{abstract}
Resumo: No conto Outros tempos, Domingos Pellegrini mostra o funcionamento da liberdade de ação no Brasil em três momentos: 1950, 1970 e 2000. A diversidade de contexto entre as situações vividas nestes três tempos é retratada pelas atitudes de três gerações de homens de uma mesma família diante da abordagem da polícia no espaço da via pública. O registro literário revela uma memória de oprimido que se torna mais dolorosa e traumática quando comparada a uma memória de enfrentamento testemunhada pelo mesmo oprimido vinte anos antes. Ambas serão transmitidas através de relato oral a um terceiro sujeito, o qual utilizará este conhecimento como experiência adquirida para criar uma vivência transformadora em sua realidade atual. Entendendo a Literatura como um lugar em que é possível a representação de realidades divergentes ou complementares, este trabalho intentará debater brevemente, a partir da análise do conto citado, alguns aspectos relacionados aos conceitos de testemunho, experiência, memória, assujeitamento e ruptura das condições de produtividade do medo instauradas pela cultura e política vigentes em dado momento histórico.
\end{abstract}

Palavras-chave: Testemunho. Memória. Medo. Enfrentamento.

\begin{abstract}
In the short story "Outros tempos", Domingos Pellegrini shows the running of the freedom of action in Brazil in three times: 1950, 1970 and 2000. The diversity of context between the three situations lived in these moments is displayed by the attitudes of three generations of the same family face to a police approach on the public area. The literary record reveals an oppressed man's memory that becomes more painful and traumatic when compared with a memory of confrontation testified by the same oppressed man twenty years before. Both stories will be transmitting in oral report to a third man who will make use of them as acquired knowledge to create a transforming experience of life in his own reality. Based on this short story and understanding the Literature as a place where is possible to represent divergent or complementary realities, this work aims to discuss briefly some aspects related to the concepts of testimony, experience, memory, subjection and breakage of the productivity conditions of fear ensured by the culture and politics valid in a historic epoch.
\end{abstract}

Keywords: Testimony. Memory. Fear. Confrontation.

\footnotetext{
${ }^{1}$ Mestranda em Teoria da Literatura do Programa de Pós-Graduação em Letras da PUCRS. Bolsista CAPES. E-mail: raquel.belisario@acad.pucrs.br
} 


\section{INTRODUÇÃO AO MEDO}

O medo é um componente imprescindível do Estado autoritário. Quando ele não se manifesta prontamente na face do indivíduo coagido, é preciso que o agente encarregado de exercer o poder em dada circunstância faça com que o medo apareça. Se ele não está completamente internalizado na vivência de uma sociedade, é possível que o cidadão ainda seja capaz de demonstrar sua força individual em atitudes de enfrentamento diante da intervenção do Estado em sua vida. Mas, a partir do momento em que a supressão de direitos civis se torna parte da realidade cotidiana, as reações do indivíduo ao controle a que é submetido passam a ser de temor constante pelas consequências que tal enfrentamento pode trazer, visto o medo estar internalizado na memória coletiva.

Há, entretanto, situações nas quais a tentativa de imposição da figura autoritária não tem o efeito suficientemente tranquilizador da ordem vigente e, nestes casos, o cidadão que enfrenta o poder da autoridade é visto com grande estranhamento, como se estivesse fora de uma "normalidade" esperada. 0 enfrentamento à autoridade é visto pelo opressor como uma atitude deliberada de insubordinação, que só pode ter suas raízes na loucura/embriaguez ou na certeza de um "poder maior" agindo por trás do indivíduo. Na dúvida se este "poder maior" realmente existe, o agente da autoridade hesita caso não tenha um suporte próprio que Ihe garanta sucesso, sem represália, em sua atitude. Porém, na certeza da inexistência desta força contrária, ou confiando nas forças que o apoiam, o agente do Estado consegue exercer sua autoridade livremente.

No conto Outros tempos, Domingos Pellegrini retrata três situações de abordagem policial a homens de gerações diferentes de uma mesma família, com reações diversas resultando de cada uma destas abordagens. O conto encontra-se no livro As sete pragas, reescrito e republicado após trinta anos e é esta versão atualizada e ampliada que analisaremos aqui. Conforme comentário do próprio autor, registrado na parte interna da capa da edição consultada para este trabalho,

"Outros Tempos" teve o enredo ampliado: passava-se em duas

épocas, com a arbitrariedade policial atingindo pai e filho; e agora 
chega ao neto que, em vez de encerrar-se na amargura da revolta contida, abre-se para a exigência lúcida da civilidade. (PELLEGRINI, 2007).

Esta exigência que propõe Pellegrini, acrescentando nova situação ao final do conto, reflete o pensamento de Ettore Finazi-Agrò sobre a representação da violência na literatura brasileira contemporânea:

\begin{abstract}
É preciso, em suma, identificar e habitar um tempo restante e virtual entre o agora e o fim, um tempo interposto em que colocar a nossa reflexão e o nosso protesto: porque o pensamento e a indignação, uma atitude lógica e uma posição ética são as instâncias necessárias, as vozes que devem continuar ecoando no vazio do silêncio, ou melhor, são aquilo que deve permanecer para além da acumulação de palavras ocas e triviais submergindo o silêncio das vítimas. (Finazi-Agrò, 2012, p. 79)
\end{abstract}

\title{
2. TRÊS TEMPOS OUTROS
}

Em uma data indefinida da década de 1970, um homem caminha pela rua de uma cidade desconhecida quando é abordado por um policial militar. $\mathrm{O}$ soldado o acusa de ser "bicheiro", chama o cabo que estava bebendo no bar e exige apresentação de documentos. Ao ouvir a palavra "documentos", o homem começa a rememorar um dia passado vinte anos antes.

Em uma tarde de 1950, ainda menino, ele acompanhara o pai em uma viagem ao Rio de Janeiro para ver a final da Copa do Mundo, Brasil X Uruguai. O narrador costura as duas histórias - intercalando presente vivido e passado rememorado -, até contar o momento após o final do jogo, quando o pai, ao ser abordado por um policial, enfrenta-o, livrando-se "num safanão" e fugindo com o menino. Enquanto lembra-se deste momento e do orgulho que sentiu do pai, o homem é chamado à realidade para enfrentar a sua abordagem policial, que segue um caminho diferente.

Trinta anos mais tarde, o homem conta ao seu filho sobre as duas abordagens presenciadas por ele: a primeira como um relato de testis (a história do pai, 1950) em que ele, menino, testemunha um acontecimento traumático; e a segunda como um relato de superstes (a própria história, década de 1970), quando ele é o oprimido, ou seja, vive o acontecimento traumático. O fechamento do conto se dá com a terceira abordagem, em que o 
filho do oprimido (3ª geração), que ouviu as duas narrativas de testemunho, aproveita-as como experiência/vivência e tenta agora mostrar seu protesto contra a violência sofrida pelo pai.

$\mathrm{Na}$ década de 1950, acreditando no Estado democrático e na sua força de trabalhador getulista, o homem pôde ter uma reação de impulso. Ao ser abordado pelo policial, no primeiro momento mostrou os documentos conforme Ihe foi solicitado. Entretanto, diante da quantidade de perguntas feitas, sentiuse invadido em sua privacidade e desrespeitado em sua tristeza (acabara de sair do jogo de final da Copa do Mundo, do qual o Brasil saíra derrotado; ele, como tantos outros torcedores, vivia então um momento com efeito de luto). Retomou a carteira da mão do policial, disse-lhe uma frase grosseira e livrou-se dele com ímpeto. Depois, mesmo com uma arma apontada para si, sem refletir muito nas possíveis consequências de seu ato de enfrentamento do medo, ele fugiu.

A história é lembrada pelo filho que testemunhou o acontecimento, porém nos é contada por um narrador distanciado, em terceira pessoa e onisciente - que toma para si a responsabilidade de contar para não esquecer - enquanto o homem vivencia uma segunda situação traumática, agora na posição de protagonista. O novo evento traumático evoca uma memória de menino que ele, agora homem, fica impedido de relatar. Sua compreensão infantil do mundo, assimilando os fatos mais por imagens do que por conceitos abstratos expressos na linguagem, à época do testemunho da história do pai e o embotamento da memória pelos vinte anos decorridos desde então se juntam ao sentimento de opressão experimentado pelo homem, coibindo a representação verbal de seu pensamento. Entra em cena o discurso do narrador, tentando abarcar toda a realidade a ser contada, como se ele próprio tivesse vivido tais situações.

Ao trazer à tona o momento em que o pai foi abordado pelo policial, o narrador se coloca no lugar do homem que foi o menino e dentro desta memória que não é sua - mas talvez possa ser - as perguntas do policial, a resposta e a fuga do pai formam um continuum que só pode ser desmembrado por uma segunda leitura mais atenta. Como não há marcas textuais que expliquem a quem pertence cada fala (aparece apenas um travessão, como 
forma de dar ênfase àquela frase em específico), embora haja discurso direto livre inserido na narração, cabe ao leitor prestar atenção às nuances do discurso para poder separar os fragmentos que o distanciamento temporal tornou uma coisa só:

O que o cidadão tinha ido fazer no Rio. Era daonde. Trabalhava no que. Aí o pai puxou de volta a carteira falando quer saber duma coisa?

- O senhor vai especular na puta que pariu!

Encostou um ônibus, o homem pegou o menino e empurrou pra dentro, o polícia gritou espera lá, cidadão! E segurou o pai pelo braço. O menino viu o pai se livrando num safanão, enquanto o ônibus ia arrancando, gritou sobe logo, pai! Viu o polícia tirando o revólver mas o pai já estava dentro, o ônibus arrancou com a porta fechando. (Pellegrini, 2007, p. 26)

A forma instintiva como o pai reagiu à abordagem policial, conforme a fala do neto cinquenta anos mais tarde, está ligada ao momento político em que houve a vivência. Naquele tempo o "cidadão" se sentia fortalecido e confiava, sobretudo, no Governo. O homem se afirma "trabalhador e getulista" e reage contando e recontando a história no caminho de volta para a pensão. Ele extravasa o stress vivido, refletindo sobre o acontecimento ainda sob a exaltação da experiência. Entre frases afirmativas e palavrões, ele reelabora o acontecimento e o verbaliza, na tentativa de entendê-lo para superar seu efeito traumático. Conforme Mario Pablo Fuks, em artigo publicado no Boletim Online do Departamento de Psicanálise SEDES,

o efeito traumático é produzido pelo excedente de angústia não passível de simbolização e não representável pelo meio da palavra. Sendo transbordadas as defesas, uma angústia automática, catastrófica, avassala o eu, impondo um estado de estupor, paralisia, inermidade, desvalimento e desamparo. Impõe-se um padecimento impossível de suportar, incompreensível, impensável e indizível. (2010)

O desfecho da história do pai ficou gravado na memória do menino como um ato heroico que o deixou orgulhoso daquele "que não era um homem forte, [...] era levinho, [...] mas não levava desaforo pra casa" (Pellegrini, 2007, p. 28). Isso contribui para a solidificação do seu trauma, uma vez que funciona como ponto de comparação com a sua história, a qual não parece oferecer motivos para ter orgulho. Ele não reagiu como o pai, num impulso. Sentiu-se 
coagido e mostrou o medo que a autoridade policial esperava. Ele vivenciou o medo do enfrentamento e deu aos agentes da autoridade a oportunidade de exercerem seu poder de acordo com o momento de ditadura militar em vigor no país naquela época. Ele não contou a história para ninguém durante anos, recalcou seu trauma e sofreu com as reminiscências.

O fato de o homem não se deter na situação que está vivendo também é sintomático do mal-estar sentido por ele. Ao mesmo tempo em que as palavras do policial são os gatilhos que o fazem recordar a circunstância vivida em 1950, esta visita ao outro tempo representa uma fuga da situação traumática do presente. Assim, enquanto o narrador conta a memória do homem, este fica suspenso entre as duas narrativas: assiste ao desenlace da abordagem vivida pelo pai e adia o enfrentamento do seu próprio medo. Toda vez que ele é trazido de volta a esta realidade, se sujeita a silenciar um discurso crítico sobre o comportamento autoritário dos policiais. Não vendo meios de protestar ou reagir como o pai fizera vinte anos antes, sua maneira de evadir-se é apenas pensar naquele dia e suas reações se tornam automatizadas: concordar com os policiais, acompanhá-los ao bar, aguardar com paciência a devolução da sua carteira etc.

Nesta parte da narrativa (década de 1970), o texto está estruturado em diálogos e intervenções do narrador. O caráter fragmentário comum à literatura do período fica por conta das retomadas da memória do ano 1950.

O neto, a terceira geração a enfrentar o medo, vive em um tempo de liberdade, em que, todavia, a arbitrariedade policial não deixou de existir. Os representantes da autoridade ainda esperam fazer o cidadão tremer e as únicas alternativas que enxergam para a reação do homem que lhes exige tratamento polido e educado na solicitação dos documentos dele e do carro, em uma blitz, são bebedeira, poder maior do que o da polícia (talvez seja filho de figurão) ou propósito específico de deixá-los em má situação (talvez seja advogado ou jornalista). É neste momento que os agentes hesitam, de arma em punho, entre impor sua força ou deixar de lado o desafio a sua autoridade. Para Seligmann-Silva:

A violência que o aparato burocrático-militar aplicou para sufocar toda oposição também bloqueou o movimento de construção de um país 
mais igualitário, que deveria estender a cidadania para todos e romper com a nossa tradição de concentração da riqueza e dos direitos nas mãos de uma burguesia tacanha e cega às questões sociais. (Seligmann-Silva, 2003, p. 38)

Esta "burguesia tacanha e cega", a que se refere Seligmann-Silva, persiste no imaginário "burocrático-militar" como mantenedora do status quo, ou seja, os representantes desta classe são reconhecidamente autorizados a desafiar o poder do Estado representado pela figura da polícia. Qualquer outro cidadão que intente realizar o mesmo ato de insubordinação, ainda que não se esteja mais vivendo uma ditadura militar, estará sujeito ao uso do poder e até mesmo da violência.

O homem que ouviu as histórias do pai e do avô e agora se posiciona diante dos agentes da autoridade, confrontando-os, ocupa na vida daquela família o mesmo espaço que a literatura vem ocupando no âmbito das narrativas de testemunho. Ele toma para si a obrigação de falar em nome dos que foram calados, tentando reverter o quadro da repressão em favor dos oprimidos. Não tendo presenciado nenhum dos acontecimentos, ele tem a capacidade de analisar com distanciamento as duas situações e indignar-se em nome do pai e do avô. E ainda, como os tempos são outros, ele agora pode verbalizar este sentimento sobre o passado, que é também indignação das outras gerações, transpondo-o para o seu presente. Contudo, assume, sozinho, os riscos que esta nova situação possa representar.

\section{CONSIDERAÇÕES FINAIS: LITERATURA COMO ENFRENTAMENTO}

Anteriormente propus que o narrador nos conta uma memória que talvez possa ser sua. Pensava, então, na possibilidade de este narrador ser o próprio homem no meio da ação, agora distanciado ainda mais dos acontecimentos e, em certa medida, refeito do trauma. Nas narrativas de memória, um tipo de narrador bastante comum é aquele que conta sua própria história depois de muito tempo, e devido às diversas transformações vividas ao longo dos anos, encontra-se desidentificado com o protagonista dos eventos. Neste caso, Pellegrini teria levado ao extremo tal desidentificação entre aquele que conta e 
aquele que atua na história, desdobrando-os em duas personae distintas dentro do mesmo conto: o narrador e o protagonista. Mas não seria difícil imaginar que o homem abordado pelo soldado nos anos 1970, após ter relatado ao filho os eventos traumáticos vividos por ele e pelo pai, tenha ouvido do filho o relato final sobre o seu comportamento durante a blitz e, assim, através do efeito catártico advindo da representação mimética pelo filho de sua experiência do real, superado a fase do trauma que o impedia de rememorar os fatos através da linguagem. Desta forma, ele consegue finalmente reorganizar os eventos, ainda que de maneira entrecortada, em um único relato.

Pellegrini fala, conforme citado acima, em abrir-se para uma "exigência lúcida da civilidade" (2007), a qual poderíamos interpretar como uma obrigatoriedade de indignar-se com os fatos do passado para não deixá-los repetirem-se no futuro. Tal exigência é feita também à literatura, da qual se espera um registro sólido e cada vez mais denso de representações dos quadros de violência e trauma vividos na cultura mundial, principalmente no século $X X$, em que a imposição do poder pelos regimes autoritários foi constante.

\section{Referências}

FINAZI-AGRÒ, Ettore. Nefas: palavras e imagens da violência na moderna literatura brasileira. In: SELLIGMAN-SILVA, Márcio; GINZBURG, Jaime; HARDMAN, Francisco F. (Org.). Escritas da violência. Rio de Janeiro: 7Letras, 2012. p. 79-89. Vol. 1.

FRANCO, Renato. Literatura e Catástrofe no Brasil: anos 70. In: SELLIGMANSILVA, Márcio. (Org.). História, memória, literatura: o testemunho na Era das Catástrofes. Campinas: Ed. da Unicamp, 2003. p. 351-369.

FREUD, Sigmund. O mal-estar na cultura. Tradução Renato Zwick. Porto Alegre: L\&PM, 2010.

FUKS, Mario Pablo. Trauma e dessubjetivação. Boletim Online do Departamento de Psicanálise. N. 13. Junho de 2010. Disponível em: www.sedes.org.br/Departamen tos/Psicanalise/boletim/noticias departamento5.html. Acesso em: 14 set. 2014. PELLEGRINI, Domingos. Outros tempos. In: As sete pragas. Belo Horizonte: Leitura, 2007. p. 15-30. 
SELLIGMAN-SILVA, Márcio. Apresentação da questão: a literatura do trauma. In: (Org.). História, memória, literatura: o testemunho na Era das Catástrofes. Campinas: Ed. da Unicamp, 2003. p. 45-58. Introdução. In: (Org.) História, memória, literatura: 0 testemunho na Era das Catástrofes. Campinas: Ed. da Unicamp, 2003. p. 7-44. . Literatura e trauma: um novo paradigma. In. O local da diferença: ensaios sobre memória, arte, literatura e tradução. São Paulo: Ed. 34, 2005. p. 63-80. 